\title{
MANIPULAÇÃO DIGITAL E ÉTICA NO FOTOJORNALISMO
}

\author{
DIGITAL MANIPULATION AND ETHICS IN PHOTOJOURNALISM
}

MANIPULACIÓN DIGITAL Y LA ÉTICA EN EL FOTOPERIODISMO

\author{
João Batista Freitas Cardoso \\ Professor no PPGCOM-USCS \\ jbfcardoso@uol.com.br
}

\begin{abstract}
Resumo
O presente texto objetiva tratar da dimensão ética na manipulação digital na fotografia jornalística. Parte-se do princípio de que, no jornalismo, a fotografia apresenta-se como uma das principais evidências de autenticidade dos fatos. Contudo, com o uso dos recursos digitais de edição de imagens, a credibilidade das representações, e até mesmo dos fatos, passa a ser posta em dúvida. Conclui-se no estudo que o problema não está na edição digital em si, mas sim nos interesses - comerciais, políticos, culturais, religiosos etc. - que motivam essas alterações.
\end{abstract}

Palavras-chave: Fotojornalismo. Manipulação Digital. Ética.

\begin{abstract}
This paper aims to address the ethical dimension in digital manipulation in journalistic photography. It starts from the principle that, in journalism, photography presents itself as a major evidence of authenticity of the facts. However, with the use of image editing digital resources, the credibility of the representations, and even the facts, becomes questionable. It was concluded in the study that the problem is not in the digital issue itself, but in the different interests - involved such as commercial, political, cultural, religious etc. - that motivate these changes.
\end{abstract}

Keywords: Photojournalism. Digital Manipulation. Ethics.

\section{Resumen}

En este trabajo se pretende abordar la dimensión ética de la manipulación digital en la fotografía periodística. Se parte del principio de que, en el periodismo, la fotografía se presenta como una evidencia importante de la autenticidad de los hechos. Sin embargo, con el uso de los recursos digitales de edición de imagen, la credibilidad de las declaraciones, e incluso los hechos, se vuelve cuestionable. Se concluye en el estudio que el problema no está en la misma edición digital, pero en los diferentes intereses implicados - comerciales, políticas, culturales, religiosas, etc. - que motivan estos câmbios.

Palabras clave: Fotoperiodismo. La manipulación digital. ética. 


\section{INTRODUÇÃO - fotojornalismo e representação da realidade}

A principal questão que se coloca na discussão ética sobre as alterações digitais da imagem na fotografia jornalística é: Até que ponto esse tipo de representação mantém vínculo com a realidade? Dessa, surge um desdobramento: Até que ponto qualquer tipo de representação mantém vínculo com a realidade? Esses questionamentos motivam as primeiras reflexões desta pesquisa.

Kossoy (2002, p. 19) escreve que a fotografia ganhou o status de credibilidade devido à sua natureza fisicoquímica "de registrar aspectos (selecionados) do real, tal como estes de fato se parecem”. Essa circunstância fez com que o sistema, desde o início, servisse como uma maneira de registro para auxiliar na compreensão da história. Segundo Peter Burke (2004, p. 25), George Francis, em uma conferência em 1888, "recomendou a coleção sistemática de fotografias como 'a melhor forma possível de retratar nossas terras, prédios e maneiras de viver"”. A metáfora da fotografia como "sombra petrificada", desenvolvida por Dubois (apud AVANCINE, 2012, p. 51-52), expressa bem a idéia corrente no século XIX do potencial fotográfico: como uma representação que é capaz de reproduzir o mundo como ele é, por deixar marcas na superfície sensível do filme no momento exato em que obturador é disparado. Nas palavras de Kossoy (2001, p. 44): “Toda fotografia representa em seu conteúdo uma interrupção do tempo e, portanto, da vida. O fragmento selecionado do real, a partir do instante em que foi registrado, permanecerá para sempre interrompido e isolado na bidimensão da superfície sensível”. Em virtude dessa natureza, segundo Dubois (2009, p. 25), havia um consenso na época de que o registro fotográfico podia "prestar conta do mundo com fidelidade". Assim, foi atribuída à fotografia, em função de seu processo mecânico, uma credibilidade que, até então, nenhum sistema anterior teria gozado.

Dubois (2009, p. 26) divide em três fases as diferentes abordagens teóricas que pretendem entender a fotografia a partir da sua relação com a realidade: (1) como espelho do real - "atribuído à semelhança existente entre a foto e seu referente"; (2) como transformação do real - não como um espelho neutro, mas como um instrumento culturalmente codificado; (3) e como traço de um real - quando há um sentimento de realidade mesmo havendo a consciência dos códigos utilizados em sua elaboração. Na primeira fase, considera-se que a representação é resultado de uma suposta neutralidade do aparelho fotográfico (2009, p. 32). Nesse sentido, a semelhança da representação com o objeto está no nível da iconicidade - nos termos de Peirce (2003). Na segunda, que se desenvolveu nos estudos da semiótica e psicologia da percepção, a fotografia é compreendida como um tipo de texto codificado sob o ponto de vista estético, cultural, sociológico etc. (DUBOIS, 2009, p. 36-37) - predomina aqui 
o legi-signo peirciano. Nessa fase, utilizando como base Arnheim, Dubois lembra que os limites da fotografia, no que se refere à sua comparação com o objeto representado, estão, entre outros fatores, na determinação de um ângulo de visão particular (2009, p. 38). Na terceira fase, recorrendo novamente às ideias de Peirce, Dubois (2009, p. 49) destaca o aspecto indicial da fotografia: a semelhança, o ícone, "deve-se na realidade ao fato de que essas fotografias foram produzidas em tais circunstâncias que eram fisicamente forçadas a corresponder detalhe por detalhe à natureza". Nessa fase, o interesse recai justamente sobre a natureza técnica do processo fotográfico "o princípio elementar da impressão luminosa regida pelas leis da física e da química" (DUBOIS, 2009, p. 50).

Sontag (2004, p. 170) destaca que essa última crença não se dá por acaso. Diferente de uma pintura ou desenho, que é apenas uma interpretação do real, a fotografia "é também um vestígio, algo diretamente decalcado do real, como uma pegada ou máscara mortuária", é o registro material de seu tema; o registro das ondas de luz refletidas pelo próprio objeto retratado. Dessa maneira, as fotos teriam o direito de reclamar para si a verdade que não caberia a pintura (SONTAG, 2004, p. 102).

No programa de realismo da fotografia, para Sontag, está contida também a idéia de que a fotografia revela uma realidade oculta. Idéia essa que ganha novos contornos nos dias de hoje com os equipamentos que captam imagens microscópicas ou imagens em rápida velocidade. O aparelho, nesse sentido, seria capaz de desvelar algo que não pode ser percebido, "quer se trate de algo imperceptível, partes fugazes de um movimento, uma ordem de coisas que a visão natural é incapaz de perceber ou uma 'realidade realçada' (expressão de Moholy-Nagy), quer se trate apenas de um modo elíptico de ver” (SONTAG, 2004, p. 137). Ao mostrar o que está oculto, principalmente no jornalismo, desvela-se a verdade, o real aparece. Ao apresentar-se como instrumento capaz de desvelar o oculto, a fotografia acaba servindo aos interesses de diferentes ideologias, algumas que, nitidamente, objetivam manipular a opinião pública. "E tal manipulação tem sido possível justamente em função da mencionada credibilidade que as imagens têm junto à massa, para quem, seus conteúdos são aceitos e assimilados como a expressão da verdade" (KOSSOY, 2002, p. 20).

Sontag entende ainda que, ao contrário de apenas se limitar a reproduzir a realidade, a representação fotográfica "recicla-a". Nesse processo de semiose, os papéis acabam se invertendo, a realidade é "examinada, e avaliada, em função da sua fidelidade às fotos" (SONTAG, 2004, p. 103). As representações, dessa maneira, alterariam a própria noção de realidade ao tornarem-se a principal referência para os objetos. Kossoy (2002, p. 22), por sua vez, afirma que a representação possui uma "realidade própria" que não corresponde 
necessariamente, e exatamente, à realidade que envolve o objeto registrado: "Trata-se da realidade do documento, da representação: uma segunda realidade, construída, codificada”. Burke (2004, p. 175) lembra que as lembranças dos acontecimentos, atualmente, estão intimamente relacionadas aos registros fotográficos. Desde lembranças de fatos nacionais ou internacionais até as nossas lembranças pessoais, familiares, são determinadas, de certa maneira, pelas representações fotográficas que temos ao nosso redor em todos os momentos. É o nível de realismo dessa segunda realidade que tomaremos, muitas vezes, como realidade.

Dubois (2009, p. 53) também entende que a fotografia como traço do real, como signo indicial, marca apenas um momento do processo: "A foto é em primeiro lugar índice. Só depois ela pode tornar-se parecida (ícone) e adquirir sentido (símbolo)”. Considerando a tríade peirciana (PEIRCE, 2003, p. 63-76), o índice, primeiro nesse processo, remete aos traços materiais deixados por um objeto que estava diante da câmera em um dado momento, o que permite gerar a representação que indica um existente particular; o ícone é a base para o reconhecimento, que permite identificar, por meio da semelhança, a imagem representada; o símbolo, por sua vez, atua no processo de rememoração, ao gerar relações com o contexto da própria foto e com os aspectos culturais externos a essa.

Para Flusser (2011, p. 31), as imagens técnicas, representações fotográficas, são tão simbólicas como todas as outras representações: “A aparente objetividade das imagens técnicas é ilusória [...]. O que vemos ao contemplar as imagens técnicas não é o 'mundo', mas determinados conceitos relativos ao mundo". O aparelho fotográfico, nesse sentido, transcodifica os acontecimentos em cenas que imaginam um mundo. O problema, quando consideramos as representações visuais veiculadas em matérias jornalísticas, é que,

O caráter aparentemente não-simbólico, objetivo, das imagens técnicas faz com que seu observador as olhe como se fossem janelas e não imagens. $\mathrm{O}$ observador confia nas imagens técnicas tanto quanto confia em seus próprios olhos. Quando critica as imagens técnicas (se é que as critica), não o faz enquanto imagens, mas enquanto visões de mundo (2011, p. 30).

Como lembra Bucci (2012, p. 42), o jornalismo "é fruto dos debates que acontecem no espaço público". Seu objetivo maior é levar à sociedade versões desses debates visando à reconstituição das histórias da forma mais verídica possível. Nesse contexto, a fotografia entra como uma das evidências da autenticidade dos fatos, contribuindo para criar, nos termos de Roland Barthes, o "efeito de realidade" (apud, BURKE, 2004, p. 26). Esse suposto efeito se deve, em muito, ao caráter indicial da fotografia que permite considera-la um registro documental do evento. 
Segundo Burke (2004, p. 26), a expressão "fotografia documental", que caracteriza a prática jornalística, começou a ser utilizada nos Estados Unidos na década de 1930 "para se referir a cenas do cotidiano de pessoas comuns, especialmente os pobres". Contudo, para ele, muitos desses registros, como as fotografias de Dorothea Lange (figura 1), "foram feitas como publicidade para campanhas de reforma social [...], eram geralmente desenvolvidas para despertar a solidariedade dos espectadores" (2004, p. 27).

Figura 1 - Migrant Mother, Lange, 1936.

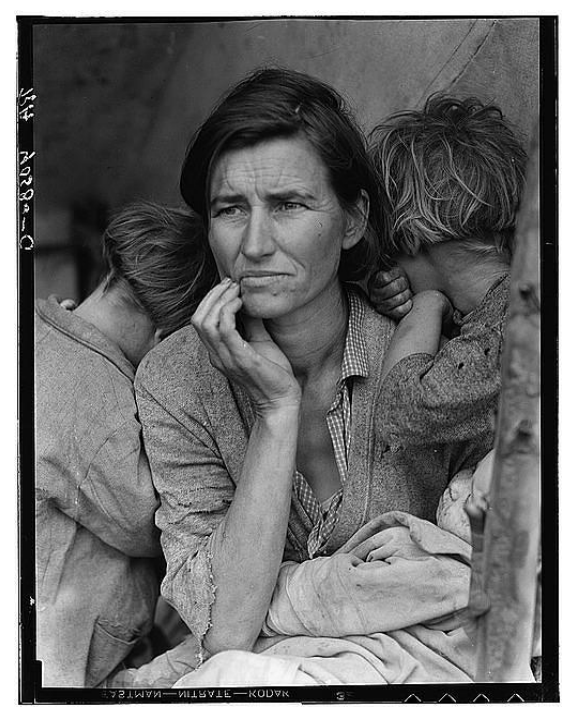

Fonte: http://www.loc.gov/rr/print/list/128_migm.html

Como a foto jornalística é também parte da história noticiada, "ésta debe construirse a partir de hechos y fuentes comprobables una a una, tal como ocurre con el texto periodístico" (DOMÉNECH FABREGAT, 2010, p. 21). A comprovação da veracidade do registro visual, que se dará em grande parte pelo texto da matéria, é um dos fatores que permite que a informação noticiada não seja posta em dúvida. Nesse sentido, se o signo visual apresenta-se como evidência do fato narrado na matéria, o signo verbal fornecerá dados suficientes que permitam verificar a autenticidade do registro. Nessa troca, a fotografia apresentar-se-ia como prova irrefutável do evento. "Decorre desta certeza universal um corolário perigoso: tudo o que a fotografia registrou é verdadeiro" (KOSSOY, 2001, p, 103). Català Domenèch (2011) alerta para o fato de que, com relação aos meios - nesse caso os jornais -, há uma cultura de que nada se interpõe entre a realidade e o receptor.

[...] tudo que inventamos para nos comunicar com ela constitui simplesmente uma ajuda para chegar mais facilmente a suas distintas facetas, mas que uma vez cumprida a função podemos retirar o instrumento e teremos obtido uma visão tão limpa da realidade como se a tivéssemos obtido com nossos olhos (supondo que pudesse ser pura nesse caso) (2011, p. 48). 
Essa crença se baseia, segundo o autor, nas teorias da comunicação que "propõe o conceito de meio para qualquer sistema de transporte de informação entre um emissor e um receptor. O meio é, segundo essa perspectiva, um simples mensageiro" (CATALÀ DOMENÈCH, 2011, p. 48). Contudo, as atuais práticas discursivas das mídias, auxiliadas pelas novas tecnologias de editoração dos produtos midiáticos, revelam que há uma gestão dos conteúdos motivada por interesses econômicos, políticos e ideológicos mais do que pelo simples objetivo de informar. Nesse contexto, para Catalá, "não pode haver, portanto, imagens neutras, muito menos se essas imagens surgem de um âmbito tecnológico que cumpre funções determinadas" (2011, p. 48).

Quando se trata especificamente dos interesses que existem nas produções fotográficas para o jornalismo, comumente considera-se o fotógrafo como um dos principais responsáveis. Sob esse ponto de vista, a credibilidade documental da foto se basearia na não-interferência do fotógrafo (MRAZ apud OLIVEIRA; VICENTINI, 2009, p. 111-112). Sontag (2004, p. 2223) também acredita que, em sua essência, a fotografia é resultado de um ato de não intervenção, mesmo que para isso o fotógrafo assuma a função de mero espectador da dor da pessoa fotografada. Para Kossoy, os componentes técnicos envolvidos no ato fotográfico (como a câmera e todos os recursos utilizados) encontram-se indissociavelmente incorporados aos de ordem imaterial, "que são os mentais e culturais". Sendo que os de ordem imaterial, para o autor, se sobreporiam hierarquicamente aos de ordem técnica. Nesse sentido, não seria possível uma não-interferência do fotografo no processo: “[...] existe sempre uma motivação interior ou exterior, pessoal ou profissional, para a criação de uma fotografia e aí reside a primeira opção do fotógrafo, quando este seleciona o assunto em função de uma determinada finalidade/intencionalidade" (KOSSOY, 2002, p. 27). Nesse processo, a seleção do assunto, dos equipamentos, do enquadramento, do momento de pressionar o obturador, da velocidade, já seria, de alguma maneira, um tipo de interferência no resultado final, determinadas em função de sua experiência, repertório, intenções etc. (2002, p. 28-29). Em virtude desses fatores, Kossoy defende a idéia de que a fotografia é "uma representação a partir do real".

Apesar de sua vinculação documental com o referente, o testemunho que se vê gravado na fotografia se acha fundido ao processo de criação do fotógrafo. O dado real, registrado fotograficamente, corresponde a um produto documental elaborado culturalmente, técnica e esteticamente, portanto ideologicamente: registro/criação. Trata-se, como vimos, de um binômio indivisivel amalgamado na imagem fotográfica (2002, p. 34-35). 
Em outro ponto do processo - não em outro extremo, como poderíamos imaginar está o público, que participa, em função de uma determinada ideologia, do "processo de construção da interpretação" (KOSSOY, 2002, p. 41-43). Nesse processo, para Kossoy, as representações fotográficas "permitem sempre uma leitura plural, dependendo de quem as apreciem". Cada pessoa possui seu próprios filtros ideológicos, culturais, éticos etc., que, de uma maneira ou outra, farão com que concordem ou não com a informação veiculada na fotografia. Contudo, o fotógrafo, tendo conhecimento de certos valores e referências do público que terá acesso à informação, buscará construir seu discurso de tal maneira que alcance o sentido desejado. $\mathrm{O}$ ângulo do fotógrafo, a princípio determinado em função de seus interesses pessoais, seria definido, então, em função de um ângulo potencial que sirva a um público específico. Ângulo esse determinado não pelo público em si, mas pela empresa de comunicação que pretende atingir esse público da maneira eficiente para atender às necessidades do mercado - venda de jornais, revistas e espaços publicitários. Para Flusser (2011, p. 74), “[...] o fotógrafo fotografa em função de um jornal determinado [...]. Ao fotografar, o fotógrafo sabe que sua fotografia será aceita pelo jornal somente se esta se enquadrar em seu programa". Mesmo com o surgimento de agências fundadas por fotojornalistas, que objetivam a independência do profissional frente aos interesses do mercado, as pautas jornalísticas das mídias permanecem na rotina dos fotógrafos "que são comissionados por diversos veículos do mundo todo" (PERSICHETTI, 2012, p. 93).

Para Avancini (2011, p. 64), as notícias se guiam exclusivamente pelo interesse do público por novidades. O programa do mercado, movido pelo consumo, faz com que os jornais necessitem cada vez mais de novas, reveladoras e surpreendentes fotografias. Em virtude disso, os fotógrafos procuram abastecer a máquina da informação de tal maneira que essa possa saciar a fome de imagens do consumidor contemporâneo. Ponto de vista divergente, mas não exatamente contraditório, é o fato de o sistema capitalista desenvolver técnicas de captação de desejo para controlar os comportamentos (STIEGLER, apud CATALÀ DOMENÈCH, 2011, 48). Sob essa ótica, a produção fotográfica não estaria submetida aos desejos do público, mas, ao contrário, os desejos do público seriam moldados por essas representações. De qualquer maneira, nesses dois modelos, não caberia ao fotógrafo a liberdade sobre o que deve e o que não deve ser mostrado, mas sim às indústrias da informação e entretenimento. Para Pinto (2002, p. 52-53), as práticas discursivas na imprensa estão submetidas a todas as dimensões, aos processos institucionais de produção, circulação e consumo dos textos. Ou seja, em certa medida, somos todos responsáveis pela construção da realidade que nos cerca. 


\section{2. ÉTICA E CREDIBILIDADE NO FOTOJORNALISMO}

Os objetivos, ou justificativas, para a edições de fotografias no jornalismo variam muito: podem ser atribuídas à solução de problemas compositivos; em virtude de correções técnicas necessárias à impressão; para intensificar a significação; ou, ainda, para iludir o público. É justamente essa prática que viola de forma mais clara as normas legais e éticas. De modo geral, no jornalismo, considera-se aceitável o retoque, ou tratamento de imagem, quando as alterações visam apenas melhorar a qualidade gráfica para a impressão. Já a manipulação é rejeitada, pois se entende que a interferência visa gerar um novo sentido aos fatos. Contudo, os limites entre "tratamento" e "manipulação" muitas vezes não se apresentam de maneira nítida, o que acaba gerando inúmeras discussões sobre as implicações éticas no uso dos recursos digitais no fotojornalismo.

Considerando a origem do termo, a ética - do grego éthos -, diz respeito "à determinação do que é certo ou errado, bom ou mau, permitido ou proibido, de acordo com um conjunto de normas ou valores adotados historicamente por uma sociedade" (MARCONDES, 2007, p. 9). A ideia de ética estaria relacionada, assim, à nossa conduta cotidiana, à "maneira pela qual tomamos decisões e assumimos responsabilidades".

Segundo Marcondes, uma das filosofias que mais inspirou o conceito contemporâneo de ética é o utilitarismo (Séc. XVIII- XIX), que tem como princípio básico a aplicação prática. Na visão do utilitarismo, as práticas éticas devem beneficiar o maior número de pessoas possível reduzindo a dor e o sofrimento. "Trata-se de uma concepção que avalia o caráter ético de uma atitude a partir do ponto de vista de suas conseqüências ou resultados" (2007, p. 116-119). Nesse sentido, as normas morais devem colocar em primeiro plano tanto os interesses de cada cidadão como os interesses da comunidade.

Foucault (1998, p. 26), ao tratar da moral, destaca o papel dos aparelhos prescritivos (como a família, a escola, a igreja etc.) ao determinarem, muitas vezes de maneira difusa, um código, que será validado ou não por cada indivíduo em função de suas ações. Nas atividades profissionais, muitas dessas condutas são sistematizadas e formalizadas para que possam orientar os profissionais no desenvolvimento de seus trabalhos. Esse tipo de norma de conduta, em princípio, é adequado apenas a um determinado grupo e em uma determinada época. No Brasil, as normas referentes à prática profissional dos jornalistas são regidas pelo Código de Ética dos Jornalistas, da Federação Nacional dos Jornalistas (FENAJ). Esse código, como os de outras categorias profissionais, atua no sentido prescritivo e normativo. Ou seja, apresenta noções fundamentais que visam restringir a liberdade do profissional e 
servir como parâmetro de conduta profissional para avaliar tanto os seus atos como os atos praticados por outros profissionais do mesmo campo.

No entanto, quando pensamos a ética sob o ponto de vista dos indivíduos, devemos sempre considerar, como lembra Habermas (2007, p. 9), que o pluralismo cultural faz com que o mundo seja "interpretado de modo diferente segundo as perspectivas dos diversos indivíduos e grupos - pelo menos num primeiro momento”. E esses modos de interpretar o mundo afetam diretamente os modos de percepção dos valores e interesses dos indivíduos. Dessa maneira, a consciência de um profissional frente aos valores de sua comunidade pode não ser compreendida por integrantes dessa mesma comunidade. Logo, os resultados, que para alguns podem ser negativos, para outros podem não ser. "É essa multiplicidade de perspectivas interpretativas que explica por que o sentido do princípio de universalização não se esgota numa reflexão monológica segundo a qual determinadas máximas seriam aceitáveis como leis universais do meu ponto de vista" (HABERMAS, 2007, p. 10).

Considerando que na prática da manipulação digital de fotografias no jornalismo estão envolvidos atores diversos (o fotógrafo, o veículo de comunicação, o público, a sociedade), com interesses distintos, pode-se pensar na questão da ética sob diferentes pontos de vista: sob a ótica da legislação e das normas de conduta profissional impostas pelo Estado, pelas organizações profissionais e pelos veículos de comunicação; sob a ótica dos aparelhos prescritivos da sociedade (a família, a igreja, a escola, as ONG's etc.); sob o ponto de vista do resultado que tal prática pode trazer a um grupo ou a toda comunidade; ou, ainda, considerando a postura ética do profissional, sob o ponto de vista da responsabilidade ética do indivíduo, como membro consciente das conseqüências de suas ações.

Independente do ponto de vista é preciso termos consciência que nenhuma norma ética resolverá todos os nossos problemas (WELLMAN apud JOHANNESEN, 2002, p. 5). Principalmente quando tratamos de uma única prática que, utilizada de diversas maneiras, com diferentes propósitos, em um sistema particular, assume uma variedade enorme de significados para seus distintos públicos.

De qualquer maneira, para Bucci (2012, p. 45) o compromisso do jornalista é com a comunicação da verdade, sem o uso de estratégias persuasivas de sedução ou que atendam a interesses de terceiros: "Em poucas palavras, o papel da ética, na história da imprensa, é proteger a credibilidade" (BUCCI, 2012, p. 46).

Durante muitos anos, a credibilidade da informação esteve ligada diretamente a ideia de objetividade e imparcialidade. "Segundo diversos manualistas, a mistura da descrição do fato com o juízo de valor é considerada inaceitável e condenável” (BARROS FILHO, 2008, p. 
18). Barros Filho (2008, p. 17-18) revela que os manuais de introdução ao jornalismo, os estudos de deontologia e os códigos de ética, sempre defenderam a objetividade como um imperativo de procedimento no jornalismo. Partindo do princípio que a objetividade era adotada pela grande maioria dos profissionais, as escolas de comunicação ensinavam os novos jornalistas a adotarem esse princípio como prática diária, rejeitando os "deslizes de subjetividade". Para alguns defensores da objetividade informativa, embora ela não possa ser atingida em sua plenitude, já que se trata de um conceito abstrato, "deve significar uma tendência, uma orientação, uma direção a ser buscada em permanência pela informação jornalística” (BARROS FILHO, 2008, p. 20-21). A objetividade é comumente associada também, segundo Barros Filho, a honestidade: “[...] é honesto quem põe todos os meios para informar-se bem; quem procura ouvir todos os lados; quem não oculta nado do que percebeu; quem não tergiversa ao que se opõe às suas opiniões"” (2008, p. 31).

Os críticos à objetividade, por sua vez, relativizaram a eficácia de um suposto “jornalismo informativo" (BARROS FILHO, 2008, p. 33). Nos Estados Unidos, as revistas semanais trocaram a crença na objetividade pela idéia de um "jornalismo interpretativo". Para os editores dessas revistas, a simples repetição objetiva das palavras ditas por uma fonte não permitem ao leitor compreender toda a complexidade dos fatos, logo, é necessário hierarquizar os elementos mais importantes da comunicação. "Luce e Hadden, fundadores do Time, propunham oferecer ao leitor não só o fato, mas 'os fatos sobre os fatos"” (BARROS FILHO, 2008, p. 18).

Contudo, independente da crença no "jornalismo informativo" ou no "jornalismo interpretativo", em princípio, a prática jornalística está intimamente ligada à problemática da “veracidade”. Para Gomes (2009, p. 11), "não há notícia sobre a qual não se imponha legitimamente uma obrigação de veracidade". Só é notícia, para o autor, um texto que comporte a pretensão de ser verdadeiro. A verdade e a mentira, nesse sentido, somente podem ser aplicadas aos textos que pretendem dizer algo sobre a realidade - uma poesia, por exemplo, não pode ser verdadeira ou falsa. Esse compromisso do jornalismo com a veracidade é assumido perante o público e a sociedade. Como bem lembra Gomes (2009, p. 34), não é raro lermos ou ouvirmos slogans como: “'Jornalismo-verdade', 'a verdade doa a quem doer', 'a verdade dos fatos em sua casa'”.

O compromisso de trazer a verdade ao leitor implica em garantir que as notícias não serão distorcidas por má-fé, interesses particulares, falta de informação, inexperiência etc. A verdade, dessa maneira, seria o desvelamento da realidade (GOMES, 2009, p. 11-12). Contudo, Gomes (2009, p. 16) adverte que a idéia ingênua de desvelamento pressupõe que os 
acontecimentos sejam estruturas estáveis, permanentes. $\mathrm{O}$ que não corresponde à realidade. Parte também do princípio de que um único olhar sobre um fato seria capaz de contemplá-lo em toda a sua plenitude. Uma informação sobre um fato não é um simples resultado do conhecimento adquirido por meio da percepção. Ao contrário disso, a informação comporta além dos acontecimentos, as experiências, valores, crenças, imaginário e repertório do repórter somados às normas de linguagem e do gênero que determinam uma maneira de contar a história. Assim, não há como desvelar a realidade se, sob o véu, há uma série de pontos de vista sobre o mesmo fato.

Contudo, o discurso da impossibilidade de retratar a realidade não pode afastar de maneira nenhuma o jornalismo do compromisso com seus princípios básicos. As empresas de comunicação, além de se orientarem por seus próprios manuais de ética, estão também submetidas ao Código de Ética dos Jornalistas Brasileiros da FENAJ (2007). No Art. $4^{\text {o }}$ do Código, a entidade já demonstra a preocupação com a questão da veracidade: "O compromisso fundamental do jornalista é com a verdade no relato dos fatos". No que se refere especificamente ao uso de fotografias e recursos digitais de manipulação, o $\S \mathrm{V}$ do Art. 12, recomenda: “O jornalista deve: rejeitar alterações nas imagens captadas que deturpem a realidade, sempre informando ao público o eventual uso de recursos de fotomontagem, edição de imagem, reconstituição de áudio ou quaisquer outras manipulações”. Ou seja, tanto no texto verbal como nas imagens, a "lei da verdade" deve prevalecer.

Em função de sua eterna relação com o real, a fotografia é o elemento que expressa de maneira mais nítida o conceito de objetividade (BARROS FILHO, 2008, p. 64), por isso, é um dos principais recursos de informação no jornalismo. Mais do que apresentar o real, no senso comum, "a imagem permite [...] conhecer um real inacessível” (BARROS FILHO, 2008, p. 72). E talvez esse seja um dos maiores problemas. Como nosso contato com a maior parte do mundo se dá apenas por meio de representações veiculadas pelas mídias, elas se apresentam para nós como parte de uma realidade distante. E essas representações, muitas vezes, serão o único tipo de contato que teremos com essas realidades.

Tomar como real a representação fotográfica é aceitar apenas seu aspecto icônico - a aparência exterior do objeto - e seu aspecto indicial - sua natureza como registro de um instante - sem considerar seu potencial simbólico, que muitas vezes é o principal elemento da comunicação. Como a discussão sobre a ética jornalística se fundamenta na veracidade da notícia, é natural que a analogia formal e a comprovação de ocorrência do fato contribuam para gerar esse "efeito de real". Contudo, aceitar uma fotografia como representação do real é ignorar que um simples recorte ou enquadramento pode também gerar uma série de novos 
sentidos que não correspondem ao objeto fotografado. Todo enquadramento, todo ângulo, todo recorte é também um tipo de discurso, e, como qualquer discurso, nunca será imparcial. O problema maior é que as realidades geradas por esses discursos, mesmo em fotografias nãomanipuladas digitalmente, podem ser adotadas em substituição ao real. A fotografia, nesse caso, apresenta-se como uma prova que legitima um ideário. "As imagens técnicas tornam as imagens mentais reais. As fantasias da imaginação individual e do imaginário coletivo adquirem contornos nítidos e formas concretas através do chamado testemunho fotográfico" (KOSSOY, 2002, p. 140).

No caso da manipulação digital, ainda que a problemática permaneça no caráter icônico do signo fotográfico, para muitos, o aspecto indicial toma novos contornos, pois a representação já não é mais um traço material do objeto originado por um processo físicoquímico. Contudo, para Gunning, o aspecto indicial da fotografia não pode ser confundido com sua iconicidade, "Um índice não necessita assemelhar-se à coisa que representa (e frequentemente não o faz)” (2012, p. 5), haja vista a maioria das informações indiciais que não são registradas como imagens fotográficas, como, por exemplo, os registros de batimentos cardíacos ou de temperatura realizados por instrumentos médicos. Para Gunning, considerar a habilidade dos recursos digitais em alterar a aparência do objeto originalmente fotografado não reduz seu potencial indicial, apenas o atenua (2012, p. 6). Para o autor, a manipulação da imagem depende, quase sempre, "da manutenção de certos aspectos da acuidade visual e da reconhecibilidade da imagem original” $(2012$, p. 7$)$.

\section{MANIPULAÇÃO DIGITAL NO FOTOJORNALISMO}

Uma manipulação fotográfica, de modo geral, pode ser realizada em diferentes fases do processo: na fase de pré-produção - na seleção e preparo do espaço, pessoas, figurino, objetos de cena etc; na produção - na escolha dos equipamentos fotográficos, no ajuste das luzes, definição de ângulo, enquadramento etc.; e na pós-produção - através de retoques e alterações manuais ou digitais.

A manipulação de fotografias na imprensa, por interesses políticos ou comerciais, não surgiu, na realidade, na chamada "era digital". Os problemas que os recursos digitais trouxeram é que o nível de sofisticação das adulterações é infinitamente superior e falta a materialidade do negativo para comprovar a adulteração. Contudo, para muitos profissionais e pesquisadores do campo da comunicação, o problema não está na manipulação em si, pois "usar imagens manipuladas digitalmente não significa manipular a verdade; a manipulação 
não está no aparato técnico, não está na câmera, está atrás dela" (OLIVEIRA; VICENTINI, 2009, p. 120). Ou seja, independente do tipo de alteração, ou da fase em que tenha sido realizado, o que tornaria uma alteração aceitável ou não, sob esse ponto de vista, seriam as intenções e interesses de todos os atores envolvidos nesse contexto. Contudo, em grande parte dos textos que tratam da manipulação fotográfica recorre-se unicamente às dicotomias: "tratamento/retoque" x "manipulação"; "alteração da informação" x "não-alteração da informação". Sempre atribuindo as decisões dessas práticas a apenas duas instâncias: o fotógrafo e a empresa de comunicação.

O retoque, quando não muda o sentido da informação, é uma conduta já institucionalizada no contexto da produção fotográfica, pois "é comum a necessidade de ajustes na imagem como equilibrar luzes e sombras, reforçar uma ou outra área que não ficou bem legível. Enfim, para atenuar as deficiências inerentes aos registros fotográficos" (CAMARGO, 2012, p.185). De maneira geral, esse tipo de prática refere-se àquele tipo de alteração na representação que visa unicamente melhorar a qualidade de impressão sem alterar o seu sentido. A imagem, nesse caso, "se diferencia da original apenas no que diz respeito à cor, brilho, contraste, saturação, exposição, etc” (ALMEIDA; BONI, 2010, p. 18). Já na manipulação "existe interferência na realidade dos fatos [...], o real pode ser transformado em ficção" (ALMEIDA; BONI, 2010, p. 18). Esse tipo de interferência no material fotográfico "é uma atitude condenada como um todo especialmente para o fotojornalismo" (CAMARGO, 2012, p. 186).

No entanto, ainda que as definições de "retoque" e "manipulação" possam identificar duas práticas distintas, uma aceita e outra condenada, o limite entre elas, em alguns momentos, parece não tão bem definido. Ainda que a retirada ou inserção digital de elementos em uma cena ou alterações formais em partes da imagem possam ser claramente identificadas como um tipo de manipulação capaz de alterar a informação, o simples ajuste de cor ou luminosidade é também capaz de gerar novos sentidos. Exemplo disso é o caso da imagem do ex-jogador de futebol americano O.J. Simpson escurecida na capa da revista Time em edição que trata do resultado do julgamento do atleta condenado pelo assassinato da mulher e de seu amigo. A mesma fotografia, feita pela polícia, foi publicada pela revista Newsweek no mesmo período sem alterações de brilho ou saturação. 
Figura 2 - Foto de O.J. Simpson nas capas da Newsweek e Time.

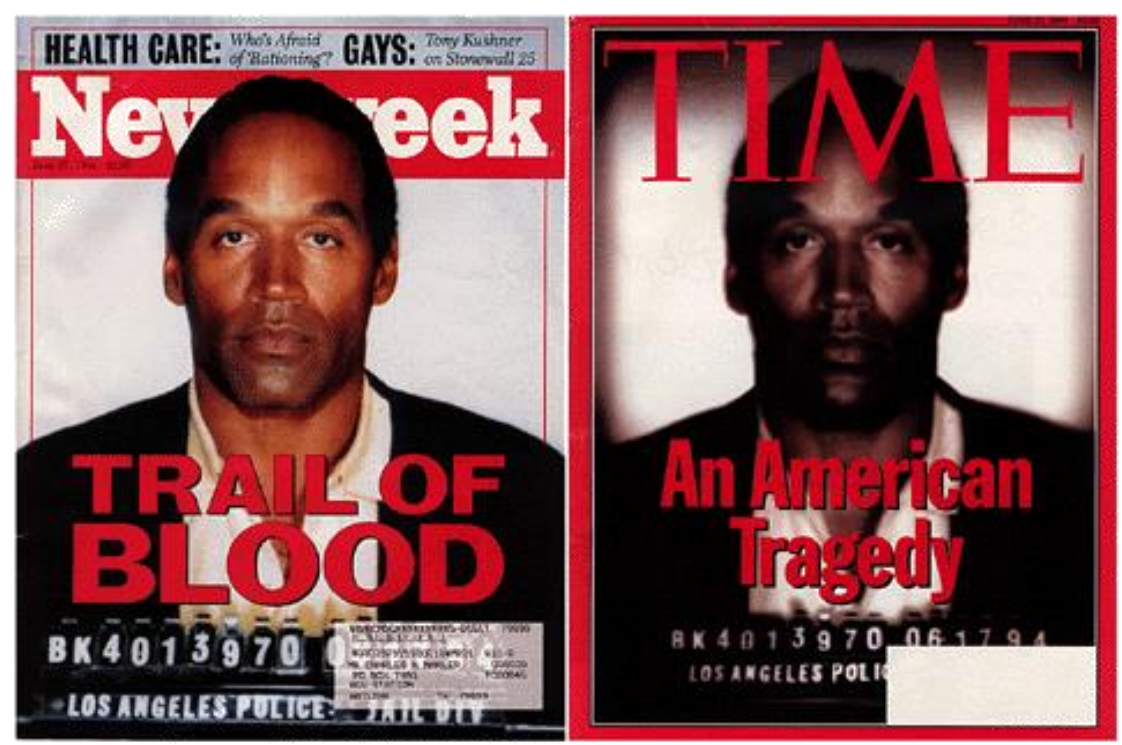

Fonte: http://www.tc.umn.edu/ hick0088/classes/csci_2101/false.html

As alterações digitais em capas de revistas e editorias, de maneira geral, são comumente aceitas no jornalismo. No caso da capa de revista, parece haver o entendimento de que essa serve como argumento para venda da revista e por isso poderia fazer uso das mesmas estratégias persuasivas aplicadas ao design de embalagem de produtos. As fotos que ilustram as matérias, por sua vez, não gozariam desse "privilégio".

A revista britânica The Economist recorreu aos recursos do Photoshop em sua capa da edição de junho de 2010 para criar uma nova situação diante de um fato. Ilustrando uma matéria sobre o vazamento de óleo no Golfo do México, a revista publicou uma foto do presidente Barack Obama, cabisbaixo, em frente a uma plataforma de petróleo. Na foto original, no entanto, Obama está ao lado de duas outras pessoas conversando. A edição feita pela revista, a partir de uma foto de Larry Downing, que pertencia ao catálogo da Reuters, consistiu em fechar o enquadramento e retirar a figura da presidente da paróquia local que acompanhava Obama no porto. Segundo o editor da revista, a fotografia foi alterada para dar mais dramaticidade ao tema. 
Figura 3 - À esquerda, capa da The Economist. À direita, foto original.

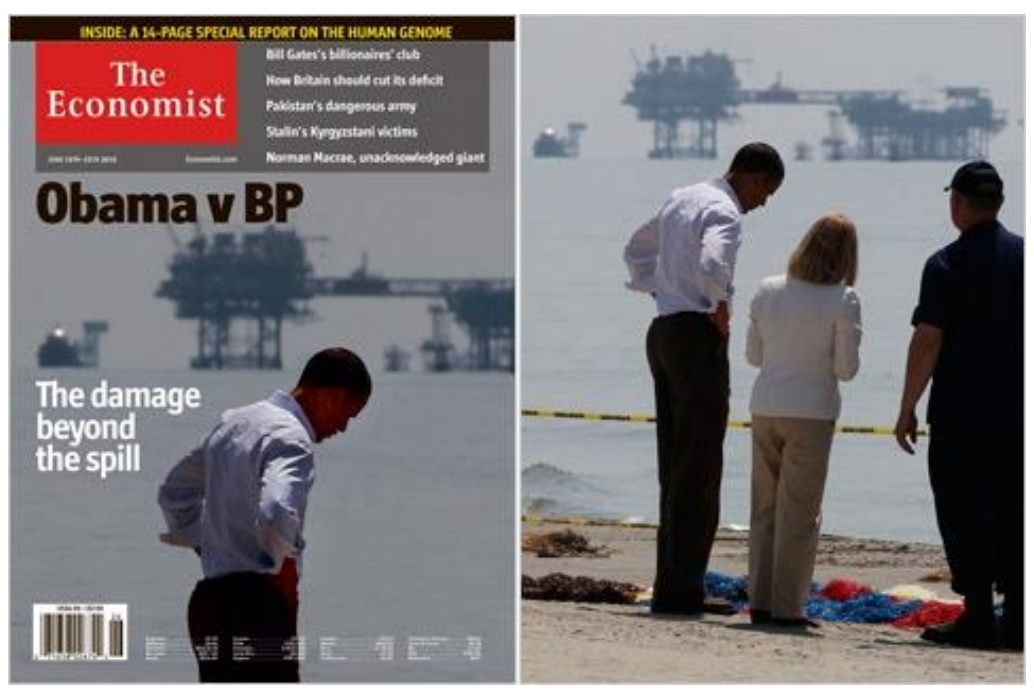

Fonte: http://www.guardian.co.uk/environment/2010/jun/13/deepwater-horizon-oil-spill-obama.

Motivada muitas vezes por interesses comerciais e/ou políticos, a substituição de elementos, com retirada de um e inserção de outro, é prática corrente. O jornal Al Ahram, publicação oficial do governo egípcio, por exemplo, publicou em setembro de 2010 uma foto do encontro de paz entre israelenses e palestinos, promovido pelos Estados Unidos, na qual o então ditador egípcio Hosni Mubarak aparece à frente do presidente Barack Obama. No entanto, a foto original, tirada em Washington, mostra o presidente dos Estados Unidos à frente de cinco chefes de estado, entre eles Mubarak. A alteração na imagem gerou protesto da Casa Branca e críticas até mesmo no Egito. A imprensa local independente considerou a iniciativa do jornal oficial uma forma de enganar a população. O jornal se defendeu dizendo que a foto foi alterada apenas para mostrar simbolicamente o papel do Egito nas negociações. “A foto expressionista é uma breve, viva e verdadeira expressão do papel proeminente que o presidente Mubarak tem na questão palestina, seu papel único ao liderar [o assunto] em Washington ou em qualquer outro local", disse Osama Saraya, editor-chefe do jornal. 
Figura 4 - Acima, foto publicada no Al Ahram. Abaixo, foto original.

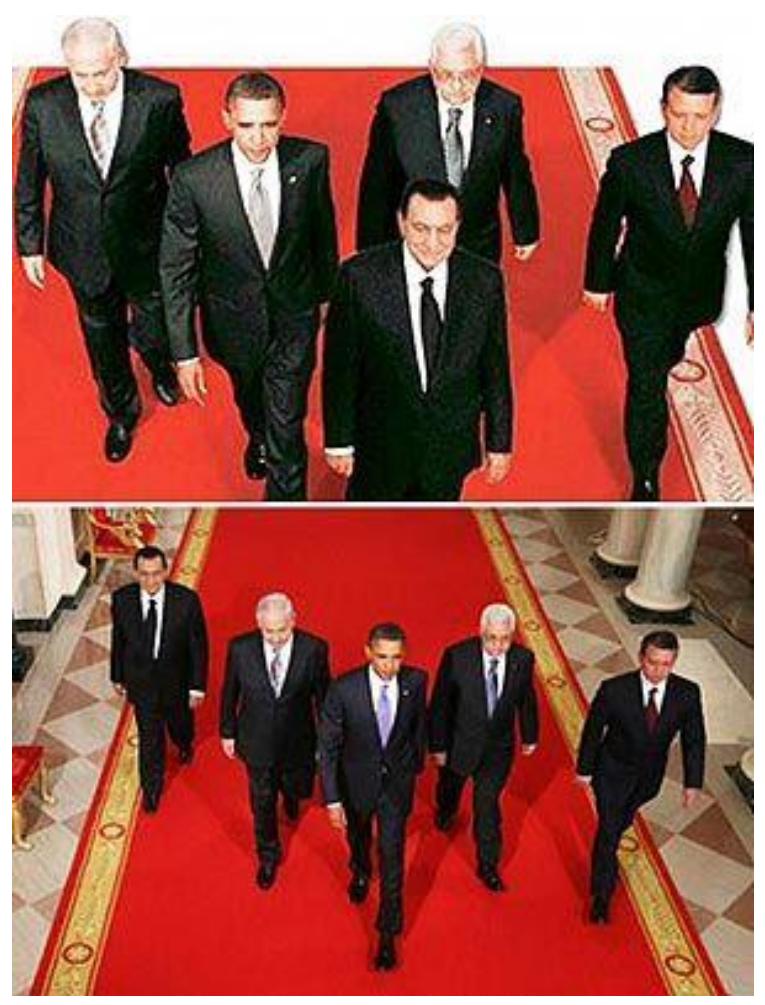

Fonte: http://www.guardian.co.uk/world/2010/sep/16/mubarak-doctored-red-carpet-picture.

Assim como a retirada de elementos da cena, a inserção ou clonagem aparecem na imprensa com alguma freqüência, e sempre vem acompanhada de duras críticas quanto à manipulação. A agência iraniana Sapah News divulgou duas fotografias diferentes sobre um exercício militar com lançamento de mísseis. Na primeira aparecem três mísseis sendo disparados e na outra quatro. A foto com três mísseis revela um dispositivo de lançamento inativo, o que indicaria a falha no lançamento e a suposta manipulação da foto.

Figura 5 - À esquerda, a suposta foto original. À direita, a suposta foto adulterada.

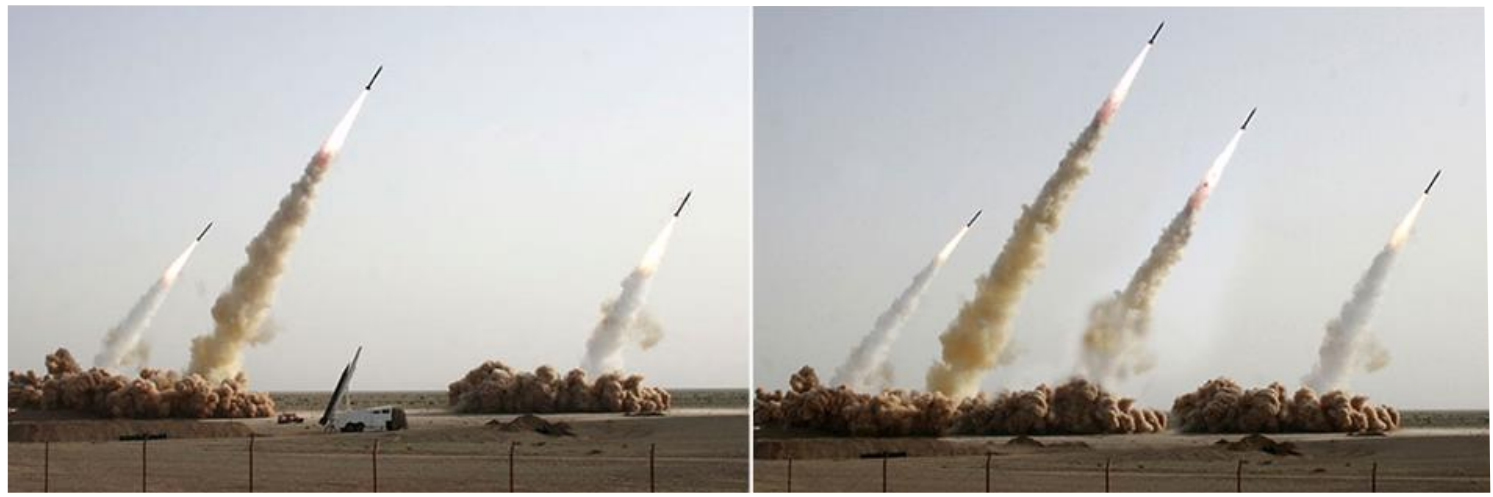

Fonte: http://g1.globo.com/Noticias/Mundo/0,,MUL642130-5602,00.html 
A British Petroleum (BP), empresa responsável pelo vazamento de óleo no Golfo do México, também fez uso da técnica de clonagem para inserir elementos na fotografia de divulgação do trabalho de monitoramento do vazamento, em seu site. Na fotografia que chegou à imprensa, a BP mostra técnicos diante de um telão composto por dez monitores acompanhando, com o auxílio de imagens submarinas, o vazamento de óleo. Na representação original, três monitores não estão funcionando, mas na imagem postada no site, todos funcionam. A BP reconheceu que a foto "exagera as atividades em suas instalações na cidade americana de Houston" e assumiu que um funcionário utilizou o programa Photoshop para acrescentar as imagens adicionais. Após a denúncia, a foto foi rapidamente retirada do site.

Figura 6 - Acima, foto manipulada com Photoshop. Abaixo, foto original.

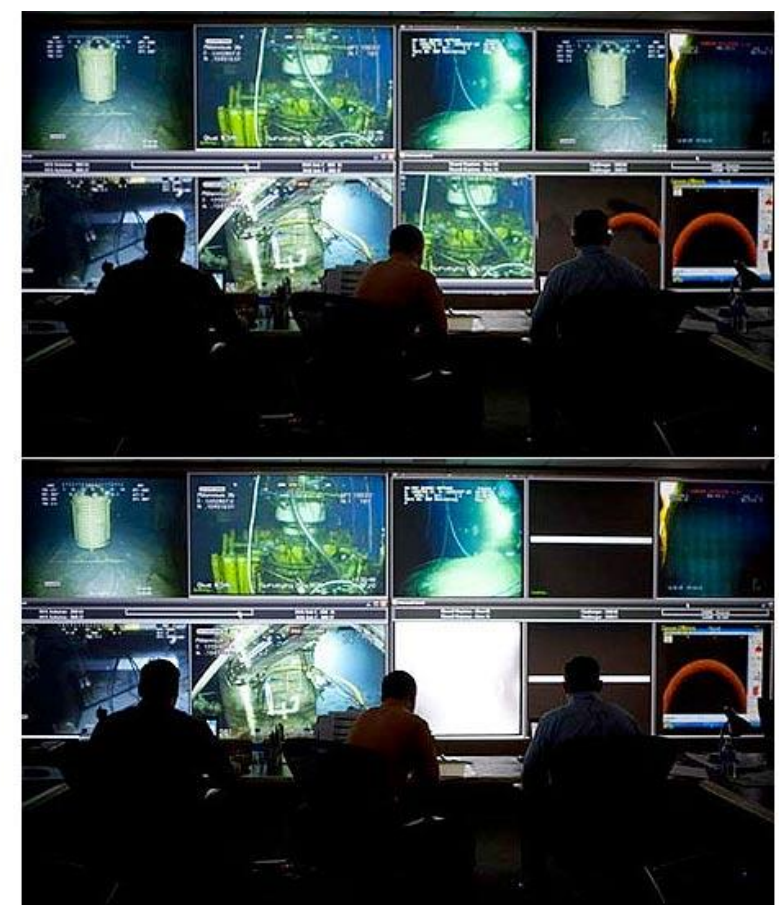

Fonte: http://www.wired.com/images_blogs/wiredscience/2010/07/bp_4a.jpg.

Não é raro encontrar na imprensa internacional alterações de fotos motivadas por crenças ou valores culturais. Nos Estados Unidos, um jornal ultra ortodoxo judaico que considera imprópria a publicação de imagem de mulher em meios públicos, o Die Zeitung, publicou uma fotografia divulgada pela Casa Branca sem as figuras da secretária de Estado Hillary Clinton e da assessora de contra terrorismo Audrey Tomason, que faziam parte da reunião que cuidava do caso Osama Bin Laden (O Globo, Mundo, maio de 2011). 
Figura 7 - À esquerda, foto no Die Zeitung. À direita, foto original.
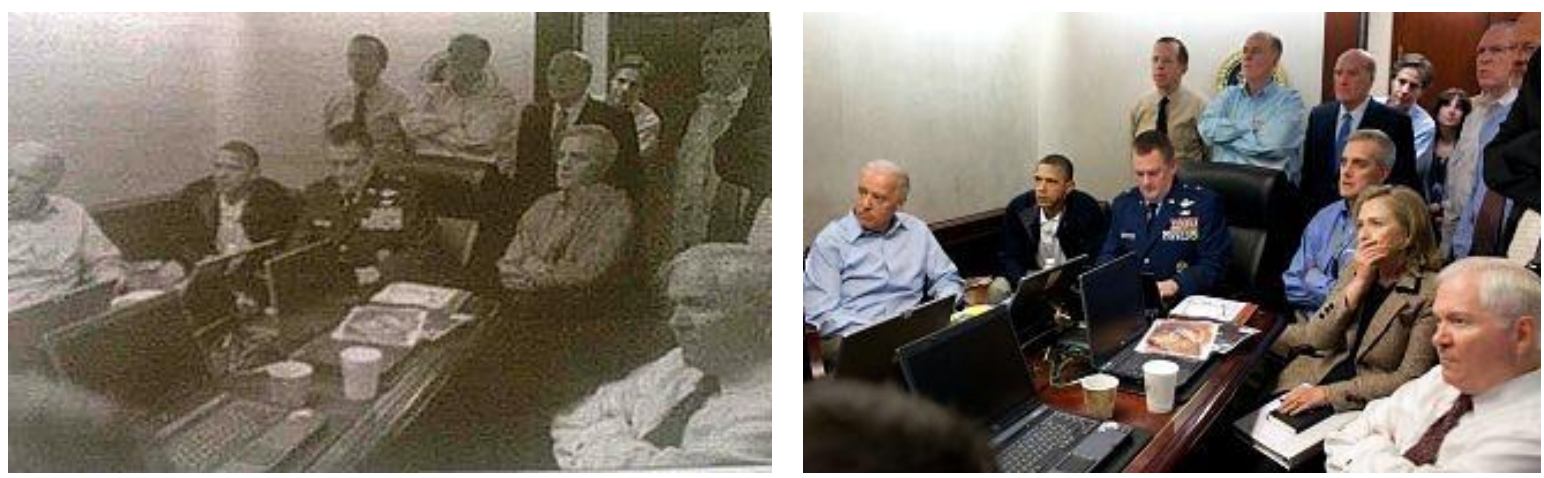

Fonte: http://www.jpost.com/International/Article.aspx?id=219660

Em janeiro de 2011, a imprensa mundial divulgou um caso de manipulação fotográfica realizado por alguns jornais iranianos. O Resalat News e Hamshahri retocaram a fotografia da chefe de diplomacia da União Européia, Catherine Ashton - que esteve em Istambul, na Turquia, para discutir o programa nuclear iraniano -, subindo em alguns centímetros o decote de sua blusa. Segundo o jornalista Cyrus Amini, que já trabalhou no Irã, esse tipo de prática é comum na imprensa local e não se trata de uma atitude ofensiva ou antiética. Ao contrário disso, foi tomada para evitar problemas, já que existem diferenças culturais nos paises islâmicos (Folha.Com, Mundo, 2011). Este caso, em particular, não foi muito criticado pela imprensa global, já que muitos consideraram que existem diferenças culturais que motivaram a manipulação.

Figura 8 - Foto original à esquerda. À direita reproduções dos jornais Resalat News e Hamshahri.

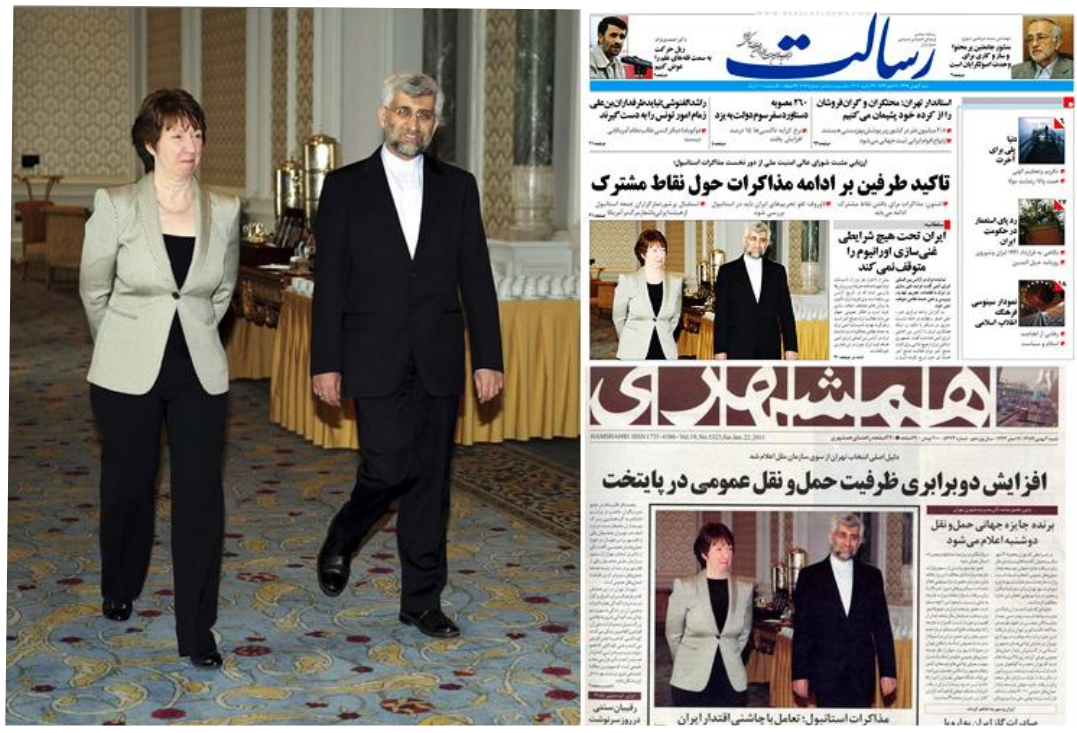

Fonte: http://noticias.uol.com.br/album/110127_photoshop_album.jhtm 
A fusão de fotos distintas para criar uma "nova realidade" também pode ser encontrada na imprensa. Brian Walski, do Los Angeles Times, realizou uma montagem, a partir de duas fotos gerando uma nova informação que não estava presente nos dois originais.

En la primera un soldado inglés está en primer plano y camina junto a la población iraquí que yace en el piso pero no apunta su arma; al fondo se observa a un hombre con un pequeño en brazos, el gesto que emana su rostro se podría interpretar como de congoja o de angustia. En la segunda, el soldado ha levantado su arma con el brazo derecho, mientras el izquierdo hace algunas señas a la población, el hombre del fondo con el niño que vimos en la anterior está más bien lejano, es total mente secundario en la escena ya que ni siquiera se le observa bien, otros iraquíes en el piso sólo miran al militar. El fotorreportero en una suerte de conjuntar ambos documentos trabajó digitalmente y creó una gráfica que no existió más que en su interés por reforzar un discurso (NASR, 2007, p. 12-14).

Figura 9 - À esquerda, original 1 (acima) e original 2 (abaixo). À direita, fotomontagem.
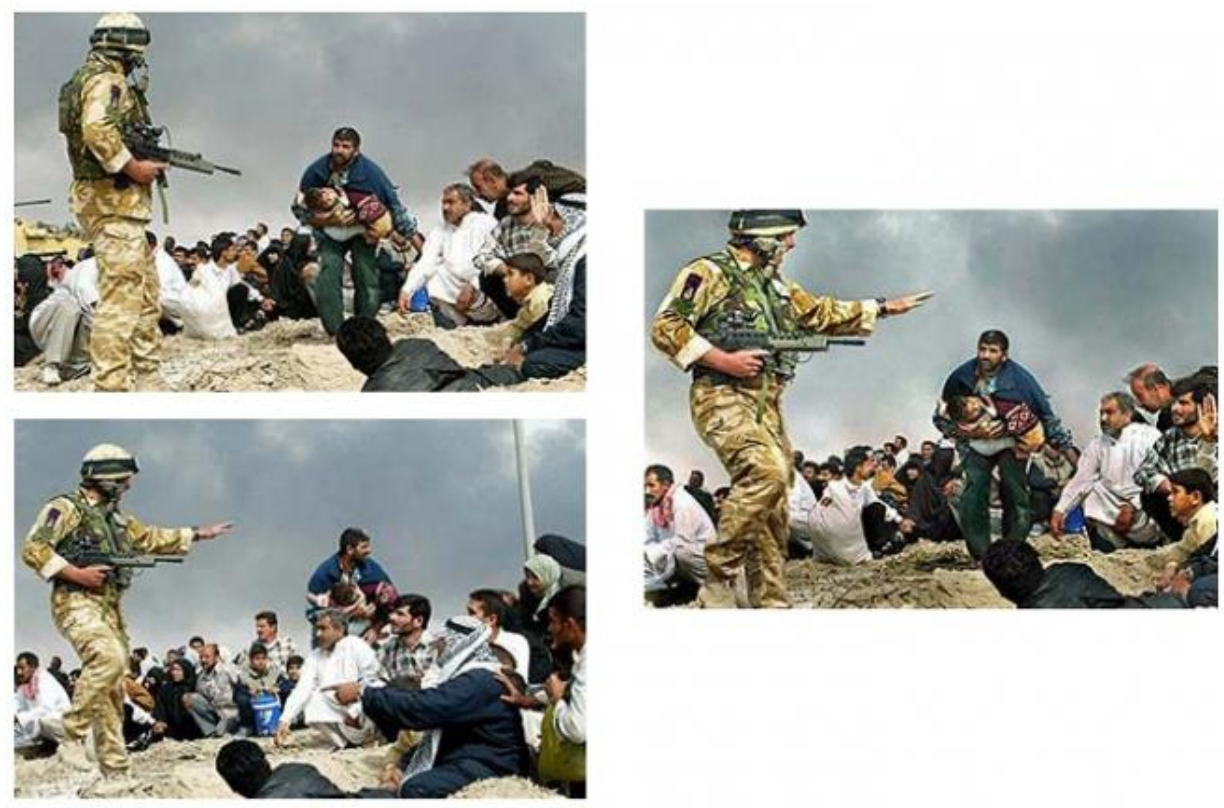

Fonte: http://www.nytimes.com/2006/08/14/technology/14photoshop.html?_r=0.

A notícia da morte de Osama Bin Laden também foi alvo da manipulação por montagem de diferentes fotos. Com o título Un muerto de 'photoshop' o jornal espanhol El mundo divulgou a descoberta de fraude na imagem divulgada pela emissora paquistanesa Geo, que mostrava o suposto rosto do terrorista morto - publicada em diversos jornais, na internet e televisão em várias partes do mundo. A manipulação partiu de uma foto de Bin Laden tirada em 1998, combinada com parte do rosto desfigurado de um outro homem. 
Figura 10 - Montagem da foto de Osama Bin Laden morto.
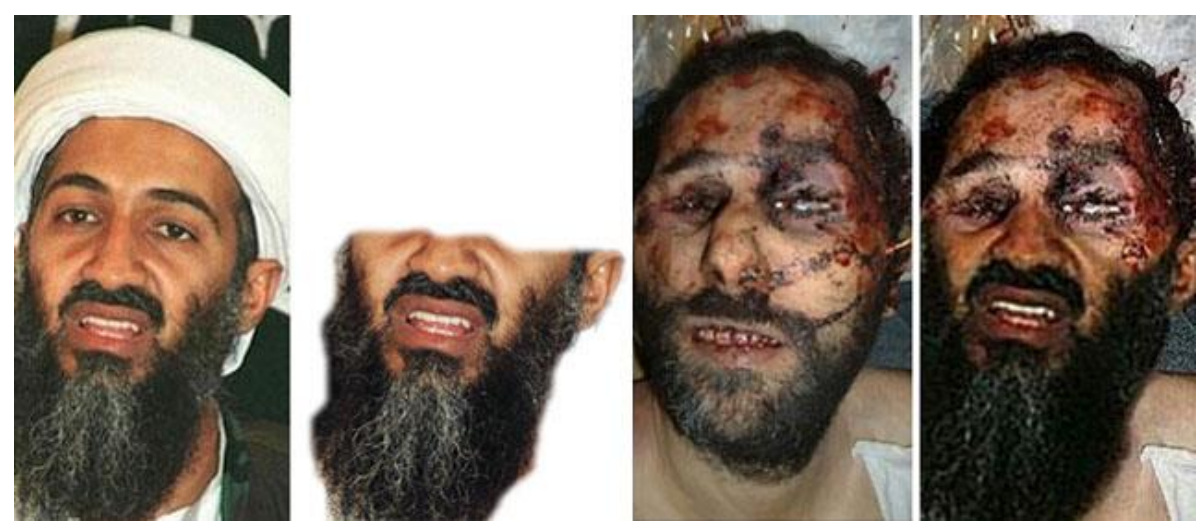

Fonte: http://www.elmundo.es/america/2011/05/02/estados_unidos/1304326652.html.

\section{CONSIDERAÇÕES}

Partindo do princípio de que um dos principais objetivos do jornalismo é trazer à sociedade fatos da forma mais verídica possível, não há como negar que a prática jornalística está intimamente ligada à problemática da "credibilidade". A notícia, nesse sentido, deve ser crível, seja ela do campo da política, arte, esporte ou ciência. A credibilidade nos fatos, por sua vez, depende da maneira como signos de diferentes naturezas (verbais, visuais e sonoros) materializam-se em textos, títulos, gráficos, ilustrações, fotografias etc. Não basta que as representações sejam fiéis aos fatos, é preciso que elas também pareçam fiéis. Nesse contexto, para que a fotografia apresente-se como um dos elementos que colabora para evidenciar a autenticidade dos acontecimentos, é necessário que os atores envolvidos nos processos institucionais de produção e circulação de imagens cuidem para que as interferências, que naturalmente ocorrem no processo de produção e pós-produção, não aumentem a distância entre à representação e os fatos que essa representa.

Ainda que a manipulação de representações visuais não seja algo recente e que à problemática da credibilidade acompanhe toda a história do jornalismo, o desenvolvimento das tecnologias digitais de captação e edição de imagens trouxe uma série de novos problemas para pesquisadores e profissionais da área: (1) a rapidez e facilidade como as imagens podem ser alteradas solicita a consideração de que, em nossos dias, as manipulações podem ser realizadas em um período de tempo tão curto que muitas vezes impossibilita o acesso da sociedade à representação original. Muitas vezes, as fotos chegam às agências e empresas de comunicação já alteradas e são publicadas dessa maneira. (2) A falta de registro original também se apresenta como um novo problema à medida que, muitas vezes, torna impossível a comprovação da prática da manipulação. A representação, nesse caso, mantém poucos, ou 
nenhum, traço do registro original. (3) $\mathrm{O}$ fato de os mesmos recursos digitais utilizados na manipulação serem também utilizados para resolução de questões técnicas relacionadas ao processo de impressão acaba fazendo com que os limites entre o que é manipulação, alteração dos fatos, e o que não é não apareça de maneira clara.

Outro problema que surge na imprensa contemporânea, e que não é resultado da manipulação em si, mas sim do excesso de divulgação dessas práticas pela própria imprensa, é o aumento no número de acusações de fraudes, que muitas vezes são equivocadas. Em agosto de 2011, a imprensa se ocupou da divulgação de uma suposta fraude em uma fotografia divulgada pelo site $T M Z$. Na foto, o empresário Steve Jobs aparece, entrando em um hospital, visivelmente debilitado. Assim que a foto foi divulgada, o site TJ's Daily questionou a veracidade da informação. Para provar a manipulação foi desenvolvido um infográfico, que circulou também por todo o mundo, apontando os indícios da adulteração: deformações sugeridas por bolinhas no rosto; marca de corte da imagem na altura do pescoço; tornozelo invertido; perna direita cortada e transformada para coincidir com o lado esquerdo frágil. Contudo, a Grosby Group, agência responsável pela imagem, confirmou a veracidade da foto. Pouco mais de um mês depois da foto, Jobs faleceu.

Figura 11 - Infográfico desenvolvido para comprovar a manipulação fotográfica.

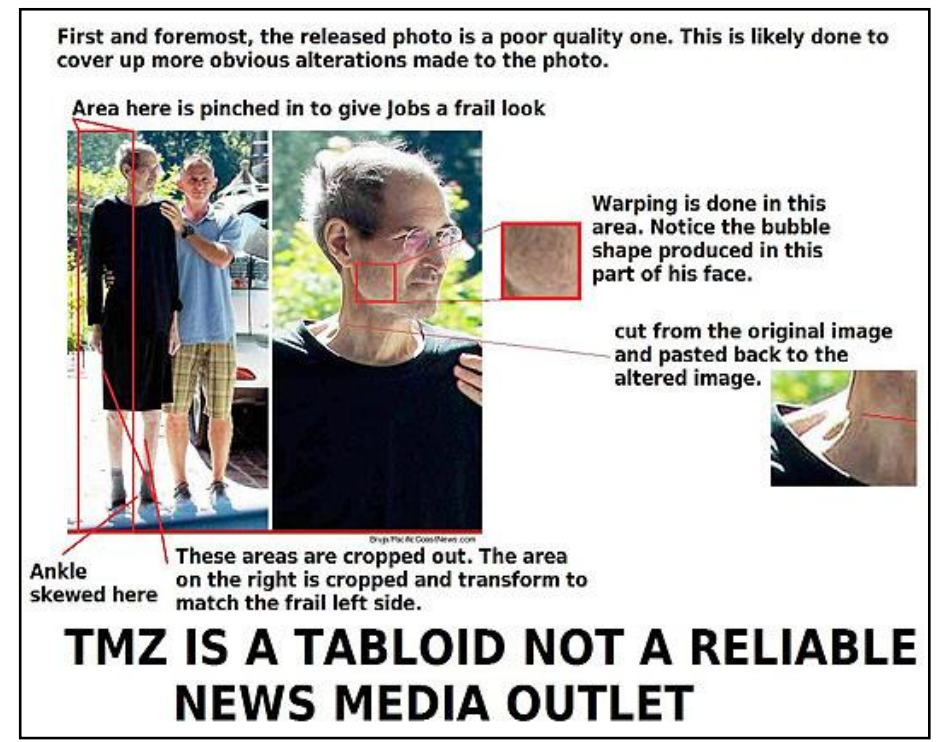

Fonte: http://www.tjsdaily.com/2011/08/steve-jobs-cancer-picture-fake.html.

As implicações éticas, dessa maneira, devem ser pensadas a partir da ótica da prática profissional assim como dos interesses do cidadão e da sociedade. É preciso considerar que existem diferentes modos de interpretar o mundo, que estão relacionados aos modos de 
percepção dos valores e interesses de cada indivíduo e cada sociedade. Nesse sentido, o problema não está na alteração digital em si, mas sim nas intenções e interesses - motivados por fatores econômicos, comerciais, políticos, culturais ou ideológicos - de todos os atores envolvidos nesse contexto e no quanto esses interesses podem afetar de maneira negativa uma dada comunidade ou um cidadão.

Mesmo que a crença no vínculo natural da representação fotográfica com a realidade não se sustente diante de uma análise mais crítica, mesmo que se considere o potencial simbólico da foto jornalística, é preciso ter em conta que o leitor comum não está em permanente estado de prontidão para duvidar de qualquer representação que encontre nas páginas do jornal ou da internet. Não há como negar que essas representações são percebidas pelo leitor comum como representações do real. Nesse sentido, a missão dos profissionais da imprensa, empresas de comunicação e organizações institucionais que regem a prática jornalística deve ser a de cuidar da manutenção na credibilidade dos fatos, independente do tipo de recurso digital que possa ser utilizado em uma edição fotográfica.

\section{REFERÊNCIAS}

AVANCINI, A. The photographic image of everyday life: meaning and information in journalism. In: Brazilian Journalism Research, vo. 7, $\mathrm{n}^{\circ}$ 1, 2011. Disponível em: <http://bjr.sbpjor.org.br/index.php/bjr/article/view/305/286>. Acesso em: 06 jan. 2012.

BARROS FILHO, C. de. Ética na Comunicação. São Paulo: SUMMUS, 2008.

BUCCI, E; AUGUSTO JR, S. N. A liberdade de imprensa e a liberdade na publicidade. In: Revista Comunicação, Mídia e Consumo. São Paulo: ESPM, 2012. pp. 33-48.

BURKE, P. Testemunha Ocular - História e Imagem. Bauru: EDUSC, 2004.

DOMÉNECH FABREGAT, H. La fotografía informativa en la prensa generalista. Del fotoperiodismo clásico a la era digital. Tese de Doutorado apresentada ao Departamento de Filosofia, Sociología e Comunicação Audiovisual e Publicidade da Universidade Jaume. Castellón, 2005. Disponível em: < http://www.tesisenred.net/ >. Acesso em 27 dez. 2012.

CAMARGO, I. A. Ética, imagem e fotografia na mídia informativa impressa. In: Revista Discurso Fotográfico. V. 8, nº 12. Londrina: UEL, 2012. pp. 161-194.

CATALÀ DOMENÈCH, J. M. A forma do real: introdução aos estudos visuais. São Paulo: Summus, 2011.

DUBOIS, P. O ato fotográfico. Campinas: Papirus, 2009.

FLUSSER, V. Filosofia da caixa preta - ensaios para uma futura filosofia da fotografia. São Paulo: Annablume, 2011. 
FOUCAULT, M. História da sexualidade 2: o uso dos prazeres. Rio de Janeiro: Graal, 1998.

GOMES, W. Jornalismo, fatos e interesses: ensaio de teoria do jornalismo. Florianópolis: Insular, 2009.

GUNNING, T. Qual a intenção de um índice? Ou, falsificando fotografias. In: Revista EcoPós, 2012. V.13, N.1, 1-22.

HABERMAS, J. A ética da discussão e a questão da verdade. São Paulo: Martins Fontes, 2007. (coleção tópicos).

JOHANNESEN, R. L. Ethics in Human Communication. Illinois: Long Grove, 2002.

KOSSOY, B. Realidades e ficções na trama fotográfica. São Paulo: Ateliê Editorial, 2002.

Fotografia \& História. São Paulo: Ateliê Editorial, 2001.

MARCONDES, D. Textos Básicos de Ética - de Platão a Foucault. Rio de Janeiro: Zahar, 2007.

NASR, R. M. Apreciación histórica y estética de la fotografía: un gran reto entre lo analógico y lo digital. In: História, v. 26, nº 2, 2007. São Paulo: UNESP. pp. 04-18.

OLIVEIRA, E. M; VICENTINI, A. Fotojornalismo - Uma Viagem Entre o Analógico e o Digital. São Paulo: Cengage Learnin, 2009.

PEIRCE, C. S. Semiótica. São Paulo: Perspectiva, 2003. (coleção estudos).

PERSICHETTI, S. Morte anunciada? Não necessariamente! O fotojornalismo renasce nas agências fotográficas. In: Revista Líbero. São Paulo: Faculdade Casper Líbero, 2011. Pp 93100 .

PINTO, M. J. Comunicação e Discurso. São Paulo: Hacker Editores, 2002.

SONTAG, S. Sobre Fotografia. São Paulo: Companhia das Letras, 2004.

Original recebido em: 15/07/2013

Aceito para publicação em: 04/11/2015

João Batista Freitas Cardoso

Doutor em Comunicação e Semiótica pela PUC-SP, com Pós-Doutorado em Comunicação pela ECA/USP. É professor no Programa de Pós-Graduação em Comunicação da USCS e professor na Universidade Mackenzie. 